\title{
HOMENAJE AL DR. LUIS VALCÁRCEL EN EL 80을 ANIVERSARIO DE SU NATALICIO
}

E n la historia de los pueblos existen personalidades sobrevivientes que a través de sus obras identifican el pensamiento y el carácter de cada época. No son ellos, por ciento, los factores definitorios del proceso social que en realidad se debe a la obra de los pueblos en conjunto; son, en cambio, los que mejor asimilaron su propia época y a quienes la comunidad les confió la tarea de ser representantes o sus conductores.

En el Perú, el periodo de entreguerra (1919-1939) que se inicia con el proceso de la Reforma Universitaria por un lado y la conquista proletaria de las 8 horas por otro, es la época en que surge el análisis científico de nuestra realidad, al mismo tiempo que la conciencia de su dependencia y subdesarrollo. Se levanta entonces un diálogo sobre el proceso, que exige una evolución racional de la historia; en la revisión de los hechos surgen varios métodos y se consolidan las doctrinas polares y sus intermediarios. Se cree entonces que un factor fundamental fue el contacto entre Occidente y Andes, allá en el siglo XVI y que en consecuencia, la "cuestión indígena" frente a la "cuestión hispánica" podrán ventilarse como factores contrarios definitorios de la vida peruana. Cuando se discuten las leyes, cuando se rehace la Constitución del Estado, cuando se habla del Perú en las plazas públicas o en el café, en el aula universitaria o en los púlpitos de los templos católicos, cuando se escribe poesía, cuando se pinta retratos o paisajes, cuando se escriben cuantos o novelas, cuando, en fin, se hace análisis metódico, se parte de ese postulado y el mundo peruano se parcializa hacia el "indigenismo" o hacia el "hispanismo". La posición "hispánica" estaba ya en plena descomposición y cada vez más se reconocía reaccionaria y aristocrática; los hispanófilos eran el ala derecha del proceso. El indigenismo, en cambio, era la posición de avanzada; la bandera indígena era conducida por los líderes. Habían nuevas corrientes, como el Marxismo, pero no había aún el marco social e histórico adecuado para su emergencia; por eso J. C. Mariátegui y R. Martínez de la Torre son esencialmente precursores de otra época que recién se procesa.

Valcárcel receptúa su tiempo, en aquel entonces, dirigente universitario y periodista, se inclina fervoroso por el indigenismo, que era lo nuevo, la vanguardia, y se constituye en uno de sus líderes más notables.

Pero "el indigenismo" no fue para Valcárcel una simple actitud o una militancia ideológica o política temporal, fue una conciencia del proceso y por ello dedicó su vida a configurar una teoría científica del Perú partiendo de la "cuestión indígena". La primera etapa de su búsqueda lo condujo a la Arqueología: para buscar a los indígenas "puros" anteriores al contacto con Oc- 
cidente, excavó las ruinas del Cusco y desde Saqsaywaman siguió la ruta de los cronistas para entender con el método de la historia la vida de los incas.

Pero su imagen del mundo andino no se conformaba sólo de esta manera y por eso fundó la Etnología, estudiando a los pueblos contemporáneos. Valcárcel se convirtió, entonces, en ese tipo de científico social que todos anhelamos ser en nuestro tiempo: integral. No escatimó métodos ni recursos y usando toda la ciencia disponible convirtió su indigenismo en teoría para el debate científico.

Por eso Valcárcel es el precursor de la ciencia social integrada que reclaman ahora los más jóvenes y al mismo tiempo es una personalidad fecunda que hay que estudiar necesariamente para entendernos y entender la etapa histórica más inmediata que nos precede.

Por eso el Museo de Arqueología y Etnología de San Marcos le rinde homenaje permanente. 